\title{
Relationship of Social Support and Treatment Compliance with the Quality of Life of HIV/AIDS Patients in Hospitals RAA Soewondo Pati
}

\author{
$1^{\text {st }}$ Muhammad Purnomo \\ Department of Nursing \\ Faculty of Health, Muhammadiyah \\ University of Kudus \\ Kudus, Indonesia \\ muh.purnomo@umkudus.ac.id
}

\author{
$2^{\text {nd }}$ Subiwati \\ Department of Nursing \\ Faculty of Health, Muhammadiyah \\ University of Kudus \\ Kudus, Indonesia
}

\begin{abstract}
The Human Immunodeficiency Virus (HIV) is a retrovirus (RNA group Retroviruses Ribonucleic Acid) that attack the human immune system. During the period of the year 2016 new HIV-infected sufferers amounted to 1.8 million and with mortality by as much as 1.0 million (WHO, 2016). Cases of HIV/AIDS in Indonesia ranked 13th in the world, and its development has always been on the rise since it was first found. Central Java province ranked 5th most HIV/AIDS cases in Indonesia based on the number of cumulative according to the provinces based on reports from 1 October until 31 December 2016 Penyakit HIV/AIDS is a disease that can affect the quality of live the quality of life of people living with HIV are influenced by several factors, namely the work on a physical domain and followed by physical therapy on domain compliance and independence, as well as the level of education. Social support is indispensable in order for HIV/AIDS patients can reduce the negative impact of this disease and the infection can be done by providing support and Treatment Compliance of the relationship of social support with quality of life of HIV/AIDS Patients in hospitals RAA Soewondo Pati. The type of Research used are analytic correlation his approach using shape design of Cross-Sectional research Technique sampling is random sampling with sample number 90 . There is a connection with treatment adherence to the quality of life of HIV/AIDS patients in hospitals RAA Soewondo Pati, which means ( $p$ value $=0.005$, $\alpha=0.1$, OR = 3.4), which means that the HIV/AIDS patient who dutifully seeking treatment would have had opportunities 3.4 time to have a good quality of life compared to HIV/AIDS patients who don't comply. There is a relationship of social support with quality of life of HIV/AIDS patients in hospitals RAA Soewondo Pati, which means ( $p$ value $=0.004, \alpha=0.1$, OR $=4.7$ ), that means that the HIV/AIDS patients who get social support good then will have the opportunity to have time 4.7 quality of life compared to HIV/AIDS patients who get worse social support. There is a relationship of social support and treatment compliance with the quality of life of HIV/AIDS patients in HOSPITALS RAA Soewondo Pati.
\end{abstract}

Keywords-Social Support, Treatment, HIV/AIDS

\section{INTRODUCTION}

Human Immunodeficiency Virus (HIV) is a retrovirus group of RNA (Retroviruses Ribonucleic Acid) that attacks the human immunity. The decline of the immune system in people with HIV facilitate the occurrence of infections, thus causing the emergence of Acquired Immunodeficiency Syndrome (AIDS). AIDS is a disease caused by a virus that damages the human immune system. More than 3 decades of AIDS epidemic is a big mystery because until now there is no vaccine to prevent the causative agent (immune deficiency). The HIV virus has become a very dangerous virus because no cure has been found yet. HIV treatment is only able to suppress the replication of the virus, but does not eliminate it.

WHO explains that HIV is an ongoing problem because more than 36.7 million people are infected worldwide. During the 2016 period, 1.8 million new patients were infected with $\mathrm{HIV}$ and 1.0 million in mortality [1].

HIV / AIDS cases in Indonesia ranks 13th in the world, and its development has always been increasing since it was first discovered. Therefore, HIV / AIDS is part of the Millennium Development Goals (MDGs) achievement program, and is one of the three MDGs targets that are difficult to achieve in 2015 [2]. It is made worse by the number of cases of HIV / AIDS were reported to vary. The Directorate General of P2PL Ministry of Health Republic of Indonesia reports the number of HIV AIDS from 1 October to 31 December 2016, the number of HIV cases was 41,250 cases, the number of AIDS cases was 7,491 cases. Cumulatively, HIV AIDS from 1 April 1987 to 31 December 2016, namely the number of HIV reached 232,323 people, the number of AIDS reached 86,725 people with a mortality rate of 14,608 people spread in 34 Provinces. The highest cases from DKI were 54,003 cases, the second highest in East Java 48,340 cases, while in Central Java 23,311 cases ranked fifth with the number of HIV / AIDS cases [3].

Central Java Province ranks 5th most cases of HIV / AIDS in Indonesia based on cumulative number by province based on reports from October 1 to December 31, 2016 the number of HIV cases in Central Java reached 16,867 cases, and 
reached 6.444 cases of AIDS patients. With the value of the prevalence of 19.90 per 100,000 population [3].

Based on data from the District Health Office, Pati stated that the report on the results of semester 3 evaluations from July to September 2017 Pati city was ranked 3rd in Central Java Province.

Physiologically HIV attacks the immune system of patients and if coupled with spiritual prolonged psychosocial stress will accelerate the onset of AIDS, even increase mortality AIDS is not curable, but the life expectancy of people with HIV / AIDS (ODHA) can be extended with antiretroviral treatment. This treatment can increase the immunity of ODHA so that the quality of life also increases [4].

Quality of life is considered as a subjective, multidimensional perception that is formed by the individual's physical, emotional, and social abilities including cognitive and emotional abilities or happiness. HIV / AIDS is a disease that can affect the quality of life of patients with both symptomatic and asymptomatic had low quality of life values. Quality of life is an important factor to be considered for the physical and mental health. Improving the quality of life of people with HIV/AIDS (ODHA) is very important to be improved. Other research that supports aspects of social relations generates community awareness to better understand basic needs such as family relationships and social support is an important thing to give to ODHA in order to improve their quality of life. The psychological domain also has an influence on improving the quality of life [5].

Quality of life is an individual's perception of his dignity and value in the context of culture and value systems related to life goals and expectations. Quality of life of ODHA is the functioning of physical, psychological, social and spiritual conditions so that they can live productively like healthy people in carrying out their lives. The domain of quality of life is divided into physical, psychological, independence, social, environmental and spiritual domains. The environmental domain and the social relations domain are very influential on the quality of life of ODHA. The lowest quality of life is the domain of the environment and social relations so that living conditions decline and the quality of life decreases [6].

Quality of life of people living with HIV is influenced by several factors work in the physical domain and followed by physical therapy adherence on the domain and independence, as well as the level of education. According to Kusuma [7] that the quality of life of ODHA is influenced by demographic characteristics. Based on health-related quality of life surveillance in the United States from 1993-2002, several factors that determined quality of life were found to be gender, age, ethnicity / race, marital status, education, income, employment status, health insurance, and health factors. Disa, et al. [8] explained that there were other factors that could affect the quality of life in HIV patients, namely infection, antiretroviral therapy, social support, CD4 cell counts, medication adherence, occupation, gender, symptoms, depression and family support. According to Rozi [6], the quality of life of ODHA is affected by physical, level of ARV dependence, the environment, peer support and spiritual support. Social support can help to overcome ODHA problems both physically and psychologically. Therefore, increasing social support needs to be done both from individual patients, families, ODHA observers, peer support groups and the government.
Adherence to antiretroviral therapy requires patients to take the medicine in accordance with the time it takes the dose taken by way of taking the drug. Delay in taking medication that can still be tolerated is $\langle 1$ hour. This is because more than 1 hour is a safe time span. If you are late taking medication> 1 hour will cause the virus to replicate and the virus that has been resistant will be more superior. The best way to prevent the development of resistance is by adherence to therapy. Compliance is a term that describes the use of antiretroviral (ARV) therapy which must be in accordance with the instructions on the prescription provided by health workers for patients. This includes the discipline and timeliness of taking medication [9].

Health services provided to patients with HIV / AIDS tend to still focus on physical problems alone. Whereas psychosocial problems experienced by people with HIV / AIDS are sometimes heavier than their physical burden (Sarwono, 2008)[10]. Therefore, the treatment of these patients can not only focus on physical problems but also psychosocial problems experienced by people living with HIV / AIDS (PLWHA) so that they do not have an impact on the broader problem of decreased quality of life (Abiodun, et al. 2010)[11].

Social support is needed so that HIV / AIDS patients can reduce the negative effects of infection with this disease and can be done by providing information support i.e. family or closest person as the giver of information to the patient, instrumental support i.e. family or closest people as the giver of funds to the patient, assessment support, namely the family as an identity validator for the patient, and emotional support, namely the family or the closest people as a safe and peaceful place to rest (Friedman, 2010)[12].

According to interviews from HIV / AIDS Officers at RAA Hospital Soewondo Pati, explained that from the founding of the Voluntary Counseling Test (VCT) in 2007 until now it states that HIV / AIDS patients every year always increase with an average visit of 250 people a month with compliance different treatment and social support. In Pati City has 2 active Peer Support Groups (KDS) namely Matahari Peer groups and Nayat Fatayat Peer Groups. The information obtained from the peer group coordinator said that the current quality of life of people with HIV / AIDS (ODHA) cannot be said to be good or bad, this is because individuals who differ in terms of physical or psychological, and background work or activities, as well as the time difference when the problem will occur. Here a meeting is held every 1 (one) month to discuss existing problems. And this is where trust, their solidarity grows to support others. In accordance with the work program of the central government, the Pati District Health Office considers the existence of peer support groups to be very helpful in reducing HIV / AIDS transmission rates in addition to ARV treatment. Therefore, social support must be provided in the implementation of treatment management for ODHA patients in the hope that it can improve the quality of life of ODHA.

Based on a preliminary survey conducted on January 16, 2018 at the Volontary Counseling and Testing (VCT) Clinic of RAA Soewondo Pati Hospital to 10 respondents, it was found that as many as 7 people had a good quality of life because they were obedient in taking medication and also received social support and 3 of them have a poor quality of life because they do not obediently take medicine nor do they get social support. Benchmark quality at RAA Soewondo Pati 
Hospital using CD 4 laboratory results with an ever-increasing number and patients can carry out activities as usual.

Based on the description above, researchers are interested in examining "The Relationship of Treatment Compliance and Social Support with the Quality of Life of HIV/AIDS Patients in RAA Soewondo Pati Hospital".

\section{METHOD}

The study used was analytic correlation using a cross sectional approach. The sample in this study was clients who treated at the VCT Polyclinic of RAA Soewondo Pati Hospital as many as 90 clients. Data were analyzed by Pearson product moment correlation techniques.

\section{RESULT}

Univariate Analysis

A. Characteristics of Respondents

1. Age

TABLE I. FREQUENCY DISTRIBUTION OF RESPONDENT CHARACTERISTICS BY AGE 2018

\begin{tabular}{|c|c|c|}
\hline Age & Frequency & \% \\
\hline $26-35$ & 34 & 37,7 \\
\hline $36-45$ & 35 & 38,9 \\
\hline $46-55$ & 18 & 20,0 \\
\hline $56-65$ & 3 & 3,3 \\
\hline Total & $\mathbf{9 0}$ & $\mathbf{1 0 0}$ \\
\hline
\end{tabular}

Source: Primer Data, 2018

Based on table I. it can be seen that from 90 respondents most of the ages 36-45 were 35 respondents (38.9\%), ages 26 35 were 34 respondents $(37.7 \%)$, ages $46-55$ were 18 respondents $(20 \%)$ and the lowest age is $56-65$ with 3 respondents $(3.3 \%)$.

2. Sex

TABLE II. FREQUENCY DISTRIBUTION OF RESPONDENT CHARACTERISTICS BY SEX 2018

\begin{tabular}{|c|c|c|}
\hline Sex & Frequency & \% \\
\hline Male & 55 & 61,1 \\
\hline Female & 35 & 38,9 \\
\hline Total & $\mathbf{9 0}$ & $\mathbf{1 0 0}$ \\
\hline
\end{tabular}

Source: Primer Data, 2018

Based on table II. it can be seen that from 90 respondents the sex of the respondents is the most male sex as many as 55 respondents $(61.1 \%)$ and the female gender as many as 35 respondents $(38.9 \%)$.

3. Education

TABLE III. FREQUENCY DISTRIBUTION OF RESPONDENT CHARACTERISTICS BY EDUCATION 2018

\begin{tabular}{|c|c|c|}
\hline Education & Frequency & \% \\
\hline SMP & 9 & 10 \\
\hline SMA & 56 & 62,2 \\
\hline Higher Education & 25 & 27,8 \\
\hline Total & $\mathbf{9 0}$ & $\mathbf{1 0 0}$ \\
\hline \multicolumn{2}{|r}{ Source: Primer Data, 2018}
\end{tabular}

Based on table III it can be seen that of the 90 respondents the majority were high school education totaling 56 respondents $(62.2 \%)$, Higher education totaling 25 respondents $(27.8 \%)$, junior high education totaling 9 respondents $(10 \%)$.
4. Job

TABLE IV. FREQUENCY DISTRIBUTION OF RESPONDENT CHARACTERISTICS BY JOB 2018

\begin{tabular}{|c|c|c|}
\hline Education & Frequency & \% \\
\hline Buruh/Tani & 6 & 6,7 \\
\hline PNS & 3 & 3,3 \\
\hline TNI/POLRI & 1 & 1,1 \\
\hline Karyawan & 27 & 30 \\
\hline Wiraswasta & 34 & 37,8 \\
\hline IRT & 19 & 21,1 \\
\hline Total & $\mathbf{9 0}$ & $\mathbf{1 0 0}$ \\
\hline
\end{tabular}

Based on table IV. it can be seen that from 90 respondents the majority of entrepreneurial jobs were 34 respondents $(37.8 \%)$, labor / farmer jobs were 6 respondents $(6.7 \%)$, civil servants were 3 respondents $(3.3 \%)$, TNI / POLRI as much as $1(1.1 \%)$, Employees as many as 27 respondents (30\%), IRT as many as 19 respondents $(21.1 \%)$.

5. Treatment Compliance

TABLE V. FREQUNCY DISTRIBUTION OF RESPONDENT CHARACTERISTIC BY TREATMENT COMPLIANCE 2018

\begin{tabular}{|c|c|c|}
\hline Treatment Compliance & Frequency & $\%$ \\
\hline Complied & 49 & 54,4 \\
\hline Did Not Comply & 41 & 45,6 \\
\hline Total & 90 & 100 \\
\hline
\end{tabular}

Based on table V. it can be seen that out of 90 respondents, 49 respondents $(54.4 \%)$ compliant respondents took medicine, 41 respondents $(45.6 \%)$ did not comply.

6. Social Support

TABLE VI. FREQUNCY DISTRIBUTION OF RESPONDENT CHARACTERISTIC BY SOCIAL SUPPORT 2018

\begin{tabular}{|c|c|c|}
\hline Social Support & Frequency & $\%$ \\
\hline Good & 67 & 74,4 \\
\hline Poor & 23 & 25,6 \\
\hline Total & $\mathbf{9 0}$ & $\mathbf{1 0 0}$ \\
\hline \multicolumn{2}{|c}{ Source: Primer Data, 2018 }
\end{tabular}

Based on table VI. it can be seen that from 90 respondents, respondents who received good social support were 67 respondents $(74.4 \%)$, who received poor support as many as 23 respondents $(25.6 \%)$.

7. Quality of Life

TABLE VII. FREQUNCY DISTRIBUTION OF RESPONDENT CHARACTERISTIC BY QUALITY OF LIFE 2018

\begin{tabular}{|c|c|c|}
\hline Quality of Life & Frequency & $\%$ \\
\hline Good & 43 & 47,8 \\
\hline Poor & 47 & 52,2 \\
\hline Total & $\mathbf{9 0}$ & $\mathbf{1 0 0}$ \\
\hline \multicolumn{2}{|c|}{ Source: Primer Data, 2018 } \\
\hline
\end{tabular}

Based on table VII. it can be seen that of the 90 respondents, respondents who have a good quality of life are 43 respondents $(47.8 \%)$, and those who have a poor quality of life are 47 respondents $(52.2 \%)$.

\section{B. Bivariate Analysis}

1. Relationship of medication compliance with quality of life 
TABLE VIII. THE RELATIONSHIP OF MEDICATION ADHERENCE WITH QUALITY OF LIFE IN HIV / AIDS PATIENTS AT RAA SOEWONDO PATI HOSPITAL 2018

\begin{tabular}{|c|c|c|c|c|c|c|c|c|}
\hline \multirow{3}{*}{$\begin{array}{l}\text { Treatment } \\
\text { Compliance }\end{array}$} & \multicolumn{4}{|c|}{ Quality of Life } & \multicolumn{2}{|c|}{ Total } & \multirow[t]{3}{*}{$\begin{array}{c}\text { OR } \\
(95 \% \mathrm{CI}) \\
\end{array}$} & \multirow[t]{3}{*}{$P$ Value } \\
\hline & \multicolumn{2}{|c|}{ Good } & \multicolumn{2}{|c|}{ Poor } & & & & \\
\hline & $N$ & $\%$ & $N$ & $\%$ & $N$ & $\%$ & & \\
\hline Complied & 30 & 61,2 & 19 & 38,8 & 49 & 100 & 3,4 & 0.005 \\
\hline Did Not Comply & 13 & 31,7 & 28 & 68,3 & 41 & 100 & & \\
\hline Total & 43 & 47,8 & 47 & 52,2 & 90 & 100 & & \\
\hline
\end{tabular}

Based on table VIII. it can be seen that from 90 respondents it was found that patients who adhered to treatment as many as 49 respondents where respondents who have good quality of life amounted to 30 respondents $(61.2 \%)$, and those who have poor quality of life amounted to 19 respondents $(38.8 \%)$. While patients who were not compliant to undergo treatment as many as 41 respondents where respondents who have good quality of life amounted to 13 respondents $(31.7 \%)$ and those who had poor quality of life totaled 28 respondents $(68.3 \%)$.
From the analysis results obtained $p$ value of 0.005 so it can be concluded that Ha is accepted and Ho is rejected, which means there is a relationship between treatment compliance with the quality of life of HIV / AIDS patients in RAA Soewondo Pati Hospital. The analysis also obtained OR value of 3.4, which means that HIV / AIDS patients who adhere to treatment will have a 3.4 times chance to have a good quality of life compared to non-adherent HIV / AIDS patients.

2. Relationship of social support with quality of life

TABLE IX. THE RELATIONSHIP OF SOCIAL SUPPORT WITH QUALITY OF LIFE IN HIV / AIDS PATIENTS AT RAA SOEWONDO PATI HOSPITAL 2018

\begin{tabular}{|c|c|c|c|c|c|c|c|c|}
\hline \multirow{3}{*}{$\begin{array}{c}\text { Social } \\
\text { Support }\end{array}$} & \multicolumn{4}{|c|}{ Quality of Life } & \multicolumn{2}{|c|}{ Total } & \multirow[t]{3}{*}{$\begin{array}{c}\text { OR } \\
(95 \% C I)\end{array}$} & \multirow[t]{3}{*}{$P$ Value } \\
\hline & \multicolumn{2}{|c|}{ Good } & \multicolumn{2}{|c|}{ Poor } & \multirow[b]{2}{*}{$N$} & \multirow[b]{2}{*}{$\%$} & & \\
\hline & $N$ & $\%$ & $N$ & $\%$ & & & & \\
\hline Good & 38 & 56,7 & 29 & 43,3 & 67 & 100 & 4,7 & 0.004 \\
\hline Poor & 5 & 21,7 & 18 & 78,3 & 23 & 100 & & \\
\hline Total & 43 & 47,8 & 47 & 52,2 & 90 & 100 & & \\
\hline
\end{tabular}

Based on table IX. it can be seen that from 90 respondents it was found that patients who had good social support were 67 respondents where respondents who had good quality of life totaled 38 respondents $(56.7 \%)$, and those who had poor quality of life totaled 29 respondents $(43.3 \%)$. Whereas patients who had poor social support were 23 respondents, with 5 respondents $(21.7 \%)$ having good quality of life and 18 respondents $(78.3 \%)$ having poor quality of life.

From the analysis results obtained $p$ value of 0.004 so it can be concluded that Ha is accepted and Ho is rejected, which means there is a relationship between social support and quality of life of HIV / AIDS patients in RAA Soewondo Pati Hospital. The analysis also obtained OR value of 4.7 which means that HIV / AIDS patients who get social support will have a 4.7 times chance to have a good quality of life compared to HIV / AIDS patients who do not get social support.

\section{CONCLUSION}

- There is a significant relationship between medication adherence with the quality of life of HIV / AIDS patients in RAA Sowondo Pati Regional Hospital ( $\mathrm{p}$ value $=0.005, \alpha=0.1, \mathrm{OR}=3.4$ )

- There is a significant relationship between social support and the quality of life of HIV / AIDS patients in RAA Sowondo Pati Hospital ( $\mathrm{p}$ value = $0.004, \alpha=0.1, \mathrm{OR}=4.7$ ).

\section{REFERENCES}

[1] WHO. QOL- HIV Bref. Quality Of Live HIV Bref. Dari http://www.who.inf/substance, 2002. Diakses pada tanggal 16 Januari 2016.

[2] Wardah, Fathiyah. Artikel : Tiga Target Mdgs Indonesia Sulit Dicapai 2015. Diakses Pada Tanggal 3 Januari 2018, 2013.

[3] Ditjen Pp\& Pl Kemenkes Ri. Statistik Kasus Hiv/Aids Di Indonesia (Internet) $2017 \quad$ From Http://Spirita.Or.Id/Stats/Detailstat.Php;No=8, 2016.

[4] Rachmawati. Kualitas Hidup Orang Dengan Hiv/Aids Yang Mengikuti Terapi Antiretroviral. Jurnal Sains Dan Praktik Psikologi, 27, 48-62, 2013.

[5] Hardiansyah., Ridwan,A., Dian,S,A., Kualitas Hidup Orang Dengan Hiv/Aids Di Kota Makassar, 2014.

[6] Rozi, Rahdatu Fakanur. Hubungan Dukungan Sosial Dengan Kualitas Hidup Odha Pada Kelompok Dukungan Sebaya Solo Plus Di Surakarta. Fakultas Ilmu Kesehatan Universitas Muhammadiyah Surakarta, 2016

[7] Kusuma. Hubungan Antara Depresi Dan Dukungan Keluarga Dengan Kualitas Hidup ODHA Di RSUPN Cipto Mangunkusumo, Tesis FIK UI, Jakarta, 2011.

[8] Disa et al. Faktor-Faktor yang Mempengaruhi Kualitas Hidup Penderita HIV yang Menjalani Rawat Jalan di Care Supportand Treatment (CST) Rumah Sakit Jiwa Daerah Sungai Bangkong Kota Pontianak. Universitas Tanjungpuran Pontianak. 2012.

[9] Suzana. Pasien Berdaya, Yayasan Spirita, Jakarta, 2012

[10] Sarwono, S. W. Aspek Psikososial Aids.Www.Kalbe.Id. Diakses Pada Tanggal 16 Januari 2018, 2008.

[11] Abiodun et al. Relation Ship Between Depression And Quality Of Live In Persons With HIV Infection In Nigeria, 2010. Friedman. Buku Ajar Keperawatan Keluarga Riset, Teori, Dan Praktek Edisi Ketiga. EGC, Jakarta, 2010. 